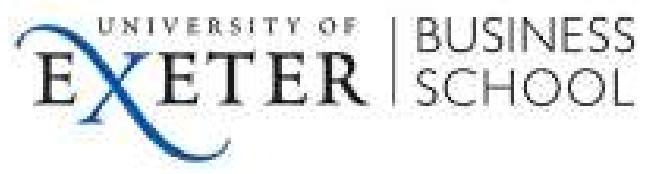

\title{
Pension Fund Deficits and Stock Market Efficiency: Evidence from the United Kingdom
}

By

\section{Weixi Liu}

$\underline{\text { W.Liu@ex.ac.uk }}$

and

Ian Tonks

I.Tonks@ex.ac.uk

Paper Number: 09/01

June 2009

The authors are both from the Xfi Centre for Finance and Investment, University of Exeter, Xfi Building, Rennes Drive, Exeter, EX4 4ST. Telephone 44-1392-263461.

This paper has benefited from seminar presentations at the University of Exeter. We are grateful for comments from David Blake and Paul Draper. Errors remain the responsibility of the authors. 


\begin{abstract}
This paper examines the effect of a company's unfunded pension liabilities on its stock market valuation. Using a sample of UK FTSE350 firms with defined benefit pension schemes, we find that although unfunded pension liabilities reduce the market value of the firm, the coefficient estimates indicate a less than one-for-one effect. Moreover, there is no evidence of significantly negative subsequent abnormal returns for highly underfunded schemes. These results suggests that shareholders do take into consideration the unfunded pension liabilities when valuing the firm, but do not fully incorporate all available information.
\end{abstract}

Keywords: Pension assets, pension liabilities, stock market transparency, FRS 17

JEL Classification: G23 


\section{Introduction}

A funded defined benefit (DB) pension scheme requires scheme sponsors to have sufficient assets to cover the pension promise, determined by a formula which takes into account the employee's wage, salary, year of service as well as any social insurance benefits. A pension deficit arises when the value of the scheme's liabilities exceeds the value of assets as a consequence of reduced valuation of the assets or increased liabilities. Pension deficits represent a true liability for the sponsoring company and should affect the firm's value on a one-for-one base if no tax and government regulations are taken into consideration ${ }^{1}$. Pension liabilities can affect a firm's earning and cash flow through both accounting and government regulations. Either the financial contribution to the plan or the amortization of the liabilities can lower the earning of the firm. Government regulations also impose compulsory contributions on severely underfunded plans. Examples include Pension Benefit Guaranty Corporation (PBGC) created by the Employee Retirement Income Security Act (ERISA) of 1974 in US and the Pension Protection Fund (PPF) in UK.

The UK pension system is distinctive in having very high levels of DB pension commitments. Although the low stock market returns in recent years, has meant that many firms have chosen to close their DB schemes in the hope of transferring the investment risk from employers to employees (evident from the hand-collected data of FTSE350 firms with DB schemes during 2001 and 2002, see section 3.4 for details). However statistics show that DB pension liabilities still amount to about 30 per cent of the overall value of major UK corporations compared to 13 per cent in the US. It is natural to ask whether the stock market correctly values these liabilities.

The correct valuation of the corporate pension liabilities not only concerns stock market efficiency but also has macroeconomic implications for national saving. This paper uses UK data for all the companies that comprise the FTSE350 stock market index with defined benefit pension schemes over the period 2001-2005, to examine whether pension fund deficits are reflected in the stock market value of the company, using two alternative empirical approaches: a market valuation approach (Feldstein and Seligman,

\footnotetext{
${ }^{1}$ For the sample period (2001-2005), in the UK, the accounting standard Financial Reporting Standard 17 (FRS17) does not require compulsory disclosure of the pension deficit on the balance sheet. The transitional regulations only require disclosure in the notes that accompany the balance sheet. The relationship between corporate debt and pension deficit will be discussed in more details in Section 3.2.
} 
1981), and an asset pricing methodology (Franzoni and Marin, 2006). The market value approach examines whether the value of unfunded pension liabilities are reflected in a company's market value. The asset pricing method examines the stock market response to subsequent corporate earnings announcements of firms with pension deficits, on the basis that any deficit will need additional contributions out of company earnings.

In the UK the newly introduced Financial Reporting Standard 17 (FRS17) enables one to get access to the fair value of pension assets and liabilities from the firm's annual report. Using data from 2001 to 2005, we estimate the effect of unfunded pension deficit on corporate share price using two alternative models. Using a sample of UK FTSE350 firms with defined benefit pension schemes, we find that unfunded pension liabilities reduce the market value of the firm but the coefficient estimates indicate a less than one-for-one effect. Moreover, there is no significant evidence of subsequent negative abnormal returns for highly underfunded schemes. The results from these two models are consistent with each other and imply that shareholders do take into consideration the unfunded pension liabilities when valuing the firm, but do not fully incorporate the information, and this causes an overvaluation of the firm. The results could also be caused by the pension contribution regulations in the UK: pension contributions made to cover the deficit are smoothed over a number of years and any financial pressures they impose on earnings are consequently weakened. As a robustness check, equivalent regressions are run using data under the most recent funding requirements.

The rest of the paper is organized as follows. Section 2 reviews the previous literature on the topic. Section 3 describes the methodology and the hypothesis to be tested following the Feldstein and Seligman (1981) and Franzoni and Marin (2006) approaches. Section 4 defines the pension plan variables and summarises the data. Sections 5 and 6 present the regression results for the market value and asset pricing models respectively. The last section summarises the paper. 


\section{Related Research on the Stock Market Reaction to Pension Deficits}

A number of papers have evaluated the stock market reaction to publicly available information on pension deficits. This literature can be broadly attributed to two main strands, namely the efficient pension liabilities valuation approach or the market valuation model, and the asset pricing methodology. This section relates this paper to these two strands and provides further explanation of the determinants of pension liabilities.

The market valuation model argues that the stock market reaction to unfunded pension liabilities depends critically on shareholders' ability to recognise that there is an obligation to make future payments to fund the promised pensions, and this realization should leave their consumption unchanged in response to the increased accounting profit, from the temporary un-funding. Feldstein (1978) discusses the relation between pension liabilities and aggregate savings by employers and employees based on these arguments.

Earlier work (Feldstein and Seligman (1981), Feldstein and Morck (1983), and Bulow, Morck, and Summers (1987)) find results consistent with the conclusion that share prices fully reflect the value of unfunded pension obligations, so the market correctly takes into account pension liabilities when valuing a company-a one dollar change of pension funding status will change the share price by one dollar (both relative to the firm's market value). However a more recent paper by Coronado and Sharpe (2003) finds evidence of overvaluation of all DB firms by looking at different measures of underlying values of net pension obligations.

Recent studies for the UK market have found that the valuation of pension deficits is subject to the choice of actuarial valuation methods such as discount rates and investment strategies (Klumpes and Whittington, 2003) and the stock market reacts differently to the pension funding status under different accounting assumptions (Klumpes and McMeeking, 2007). Besides share prices, evidence has also been found that investors tend to give different weightings to pension deficits recognised in the balance sheet as opposed to off-balance sheet deficits (disclosed in footnotes) in the 
determination of other market variables such as corporate bond spreads (Cardinale, 2005).

The market valuation model is by definition a cross-sectional test so it has low data requirements and the interpretation of the parameters is relatively straightforward. However like many other valuation models, the choice of explanatory variables (or determinant of the dependent variable) is quite 'ad hoc' (Coronado and Sharpe, 2003) and subject to individual discretion. It has a severe problem of potential omitted variables which may bias the estimation and affect the explanatory power of the model. Moreover the model does not take into account the endogeneity of pension funding status variables and the correlation (time lag) between share price and pension deficit. Last but not least, as Franzoni and Marin (2006) argue, given the low standard error for the coefficient of pension deficit, a coefficient estimate for pension deficit less than minus one cannot be rejected either, which means the model still leaves the question of overvaluation unanswered.

The asset pricing method attempts to circumvent the above problems. Rather than focusing on the determinants of market value, it uses an asset pricing model to investigate the return anomalies caused by the mispricing of pension deficits and the model is related to a body of work in accounting, in which a number of accounting items could have an influence on future earnings. For example, Bernard and Thomas (1990) report the failure of stock prices to reflect the implications of current earnings for future earnings, which is a result of systematic surprise about autocorrelated earnings.

Using US data for the past 20 years, and applying this methodology to pension deficits, Franzoni and Marin (2006) find that the decile portfolio of the most underfunded companies earn lower raw returns than companies with healthier pension schemes. This mispricing is magnified when they use the Fama and French (1993) factor model to compute the abnormal returns by looking at the difference between portfolio mean returns and the expected return estimated from the factor model. They attribute this earning anomaly to be a manifestation of the price adjustment following the negative surprise of the market. 


\section{Model Specifications}

\subsection{The Market Valuation Models}

The starting point of the market valuation model is Tobin (1969), where he sets up a general framework for monetary analysis. He argues that the market value of a firm's assets (V) should be proportional to the replacement value of the assets (A), i.e. $V=q A^{2}$. The parameter $q$ would be equal to one in equilibrium under some strict assumptions but normally this value may also depend on other variables that could affect the firm's ability to provide excess return. A higher ratio of total earning to assets $(E / A)$ or a higher growth rate of it (GROW) would increase $q$ for their positive effects on firm's profitability.

The level of corporate debt could also affect the equilibrium value of $q$. By Modigliani and Miller (1958) a firm's total market value is independent of its capital structure, thus corporate leverage would have no effect on the firm's market value under the strict M\&M assumptions. However in the real world debt may have positive or negative implications for market value of the firm - a high debt/capital $(D E B T / A)$ ratio could decrease firm's market value by increasing the bankruptcy risk or increase it because of any tax benefits. Another variable related to the perceived riskiness of a firm, and which could influence its market value is the firm's beta coefficient.

Pension liabilities are similar to corporate debt and if pension deficit has to be disclosed on the balance sheet then it represents a true liability for the sponsoring firm in accounting terms as well. If unfunded pension liabilities are not recorded in the corporate balance sheets, as in the transitional arrangements for FRS17 where only footnote disclosure is required, then pension liability and corporate debt will have some subtle differences, as described in the introduction. Pension liabilities and corporate debt are also different in terms of their tax treatments: the interest cost arising from a firm's debt is a tax deductible expense, whilst the interest income received by the pension fund (and pension contributions) is not taxed. Therefore theoretically a pound of unfunded pension liability will reduce the market value of a firm by only $1-t_{\mathrm{c}}$ where $t_{c}$ is the marginal corporate tax rate. However given the fact that many firms do not take

\footnotetext{
${ }^{2}$ Detailed definitions of the variables are presented in Section 3.4.
} 
advantage of this tax benefit, Feldstein (1978) argues that it's because shareholders anticipate this implicit tax benefit and adjust their consumption so that the reduction in firm value approaches its pre-tax level. Given the above considerations, if the unfunded pension liabilities $(P D)$ are correctly valued, they would be equivalent to an equal value of debt, but under FRS 17 transitional arrangements, they only appear as footnotes to the accounts. Therefore, unfunded pension liabilities will not decrease the current assets and will increase the accounting profit. This joint effect will reduce the relative value of the firm's market value to its total assets (i.e. $q$ ) from $1-t_{c}$ to 1 , given that the pension deficits are correctly valued by shareholders. To summarise, the total market value equation can be written

$$
\frac{V_{i t}}{A_{i t}}=\alpha_{0}+\alpha_{1} \frac{E_{i t}}{A_{i t}}+\alpha_{2} G R O W_{i t}+\alpha_{3} B E T A_{i t}+\alpha_{4} \frac{D E B T_{i t}}{A_{i t}}+\alpha_{5} \frac{P D_{i t}}{A_{i t}}+\varepsilon_{i t}
$$

where $P D_{i t}$ is the pre-tax pension deficits of company $i$ in year $t$ and $\varepsilon_{i t}$ is the error. $\alpha_{5}$ is the main coefficient of interest and should be negative and $-1<\alpha_{5}<-\left(1-t_{c}\right)$ (for the UK $\alpha_{5}$ should lie between 0.7 and 1 since the UK's $t_{c}$ was $30 \%$ during our sample period) before tax $(P D)$. If we replace $P D$ with the pension deficit after deferred tax and other non-recoverable surplus (NETPD), $\alpha_{5}$ should equal -1 . We should also observe positive values for $\alpha_{1}$ and $\alpha_{2}$. The coefficient estimates of corporate beta $\left(\alpha_{3}\right)$ and leverage ratio $\left(\alpha_{4}\right)$ are more ambiguous and depend on whether the tax benefit or bankruptcy risk dominates in the analysis.

An alternative specification is to rewrite equation (1) only including the equity components of the variables. Since the total market value of the firm consists of both equity and debt parts, those two specifications would be different from each other if one assumes different $q$ value for debt and equity. The following equity value equation assumes the market value of equity $(V E)$ of the firm is proportional to the equity asset $(A E): V E=q_{E} A E$. The complete specification of the equity value equation is similar to the total market value equation:

$$
\frac{V E_{i t}}{A E_{i t}}=\beta_{0}+\beta_{1} \frac{E E_{i t}}{A E_{i t}}+\beta_{2} G R O W E_{i t}+\beta_{3} B E T A_{i t}+\beta_{4} \frac{D E B T_{i t}}{A E_{i t}}+\beta_{5} \frac{P D_{i t}}{A E_{i t}}+\eta_{i t}
$$

where $E E_{i t}$ are the firm's equity earnings and $G R O W E_{i t}$ is the ten-year growth of the $E E$. The parameter estimations from equation (2) are expected to have similar signs to those of equation (1) but possibly of different magnitude. 
Up till now pension deficit $(P D)$ has been treated as an exogenous variable however the correct valuation of unfunded pension liabilities involves dealing appropriately with three issues: first, the tax deductibility of pension obligations; second, the accounting methods, such as the discount rate used to calculate the present value of assets and liabilities and the assumptions made for benefit and asset yields; third, the uncertainty of benefits and asset yields. Consider a firm with an obligation to pay future pension benefits, the fair value of this liability incurred will obviously depend on the tax treatment of pension expenses and thus influence the way it affects the firm's share price. Under the accounting standard FRS17 pension scheme liabilities must be measured using a projected unit method and discounted at an AA corporate bond rate so little confusion is likely to appear. However under FRS17 scheme assets are measured at 'fair value' using assumed expected returns for different investment instruments. Therefore the market value of the pension deficit depends on the discretion of different accountants. Even if the dispute about accounting methods were eliminated, the uncertainty about pension benefits and asset yields in future years still remains. This could be caused by the uncertainty about future inflation rate or real wage growth or even the possibility of the failure of the pension plan or bankruptcy of the firm. The riskiness of the securities that the pension assets are invested in can also influence the share price, as corporate debt or the beta coefficient does. A higher proportion invested in equities may increase their riskiness and thus decrease the present value of pension assets. Managers of immature pension schemes with few current pension obligations may be more willing to invest pension assets in equities which have a higher return than bonds, whilst those mature schemes that have to pay a large amount of pension benefits in a short time may be less inclined to invest in risky securities. Finally firms may deliberately leave their pension scheme with large deficits so as to take advantage of government insurance protection schemes such as the PBGC in US and the PPF in UK.

\subsection{The Asset Pricing Method}

Unfunded DB pension liabilities are likely to have negative implications for future earnings and cash flows of firms. According to Franzoni and Marin (2006) this is mainly caused by the institutional and accounting regulations that require mandatory amortization for highly underfunded schemes. If investors are unaware of this effect, when pension liabilities are due and start to affect earnings and cash flows, the investors 
will be surprised by a negative shock to earnings. As a manifestation of the price adjustment following this negative surprise, low returns should be observed for those firms with highly underfunded pension schemes.

Our measurement of a firm's funding status follows Franzoni and Marin (2006). Since it is the relative value of the pension deficit that has implications for a scheme's funding status, the pension deficit $(P D)$ is scaled by relevant variables in both the market valuation model and the asset pricing model. Franzoni and Marin (2006) use market capitalization as the scaling parameter. They argue that it is a firm's future cash flows, information diffusion and credit constraints that vary the extent to which pension deficits may affect the return. Since market capitalization is correlated to all these three variables, it is chosen as the scaling parameter. We define the funding ratio of scheme $i$ in year $t$ as

$$
F R_{i t}=\frac{P L_{i t}-P A_{i t}}{M k t C a p_{i t}}=\frac{P D_{i t}}{M k t C a p_{i t}}
$$

where $P A_{i t}$ is the pension scheme's assets and $P L_{i t}$ is its liabilities, both reported according to FRS17.

One benefit of using the above measurement is that a highly underfunded firm (with high positive $F R$ since $P D$ is defined as pension liabilities net of assets) is likely to be a small firm with high book-to-market ${ }^{3}$ ratio. Given the fact that small firms with high book-to-market usually earn high returns, if low returns are observed for those firms they are not likely to be explained by risk factors such as size or book-to-market ratio.

To assess whether highly underfunded firms earn lower risk-adjusted returns, the asset pricing model uses the calendar-time portfolio methods introduced by Lyon, Barber and Tsai (1999), who discuss an improved method for long-run abnormal returns tests. This method involves calculating the return on a portfolio composed of firms that had an event within some period of interest. Then the Fama-French three-factor factor model is applied to the calendar-time return on the portfolio to estimate the abnormal return:

\footnotetext{
${ }^{3}$ By simple manipulation $F R$ can be rewritten as $F R=\frac{P L-P A}{B o o k} \frac{B o o k}{M k t C a p}$. For a fixed first ratio, a higher $F R$ corresponds to a higher $B / M$ ratio.
} 


$$
R_{i t}=\alpha_{i}+\beta_{i} R F R M_{t}+s_{i} S M B_{t}+h_{i} H M L_{t}+\varepsilon_{i t}
$$

where $R_{i t}$ is the excess return of portfolio $i$ at time $t$ and $\varepsilon_{i t}$ is the error term. For the factors, $R M R F_{t}$ is the difference between the return of value-weighted market index and the return of the monthly return on three-month Treasury bills, $S M B_{t}$ is the difference between the returns on value-weighted small- and big-stock portfolios and $H M L_{t}$ is the difference for high and low book-to-market portfolios. The time-series estimate of the intercept $\alpha_{i}$ provides a test of the null hypothesis that the mean monthly abnormal return on the calendar-time portfolio is zero. In this paper, calendar-portfolios are constructed by sorting firms according to the funding ratio $(F R)$. Since pension data is updated annually by the requirement of FRS17, portfolios are reformed annually rather than monthly as in Lyon, Barber and Tsai (1999). If firms with large pension deficits are overvalued, the market should be negatively surprised about the deficits and as the result of the negative surprise, highly underfunded companies should have low expected returns (i.e. negative $\alpha_{i}$ ).

However as the name 'market value effect' indicates, using $F R$ to measure the funding status could cause severe problems as well. Failure to find a negative abnormal return for highly underfunded firms cannot lead to a rejection of the hypothesis that those firms are overvalued since this could just be because the positive effect of a high bookto-market ratio is so large that it dominates the negative impact of unfunded pension liabilities. Therefore in section 3.7 robustness checks are performed using different measures of funding status in the hope of eliminating this size effect.

\section{The Data}

This section reports the data selection and construction method for the regression variables. We start by discussing pension-related data mainly collected manually from the FRS17 disclosure in firms' financial reports and then non-pension related data collected from Datastream.

\subsection{Pension Plan Data}

The sample period of this paper ranges from 2001- the first year UK firms were required to disclose pension funding data in companies' reports and accounts by FRS 
17 - to $2005^{4}$. For the sample period FRS17 does not require compulsory disclosure of the pension deficit on the balance sheet. Transitional stage regulations only require disclosures in the notes that accompany the balance sheet. Not much inference can be drawn from the data prior to 2001 since before FRS17 firms were only required to publish smoothed pension costs occasionally, but this data is different from the market value of pension deficits 5 .

Pension data was manually collected for all FTSE350 companies in the UK market with at least one defined benefit pension scheme from the corporate financial statement. According to FRS17 transitional requirements, pension data can be found in the footnote to the financial statement. The statement of Financial Reporting Standard 17 by the Accounting Standard Board (ASB) defines pension scheme assets $(P A)$ and liabilities $(P L)$ and their valuation methods as following:

- Assets in a defined benefit scheme should be measured at their fair value at the balance sheet date. Scheme assets include current assets as well as investments. Any liabilities such as accrued expenses should be deducted.

- Defined benefit scheme liabilities should be measured on an actuarial basis using the projected unit method. The scheme liabilities include: (a) any benefits promised under the formal terms of the scheme; and (b) any constructive obligations for further benefits where a public statement or past practice by the employer has created a valid expectation in the employees that such benefits will be granted.

A vested pension liability (which is what appears on firm's financial statements) can be decomposed into funded and unfunded liabilities: the former means the liability is covered by scheme assets and vice versa. Obviously what matters is the unfunded pension liability, which in this paper we will call the pension deficit $(P D)$ and by definition $P D=P L-P A$. A scheme is said to be overfunded if one observes a negative $P D$ and underfunded if $P D$ is positive. NETPD denotes pension deficit net of deferred

\footnotetext{
${ }^{4}$ For the cross-sectional tests in the market valuation model (equations (1) and (2)) only data from 2001, 2002 are used. 2001 and 2002 were the first two years FRS 17 transitional arrangement was introduced. The whole dataset from 2001 to 2005 are used in the asset pricing model.

${ }^{5}$ See Section 2.5.2 for details.
} 
$\operatorname{tax}^{6}$ and other non-recoverable surplus and this is usually the term that will enter the balance sheet under the requirement of $\mathrm{FRS} 17^{7}$.

\subsection{Non-pension Variables}

This section summarises the definition and calculation methods for the non-pension variables for the empirical tests of the market valuation and asset pricing model. Detailed definitions of the variables are to be found in the appendix. These variables are constructed to be consistent with the definitions in Feldstein and Seligman (1981). All the accounting data are either found in Datastream or from Thomson ONE Banker. Datastream reports the market capitalization of each firm $(V E)$ at the end of every financial year. The equity earning $(E E)$, defined as total earnings net of the interest expense on debt, is the sum of net income available to common and preferred dividends. The book value of each firm's net debt $(D E B T)$ is defined as the sum of short term and long term debt minus cash and it is provided by the firm's cash flow statement (or its note) and to be consistent with the sign of $P D$, positive $D E B T$ means deficit and negative value stands for surplus. For the beta coefficients (BETA) the value given in Datastream is adopted.

The total market value of the firm $(V)$ is calculated as the sum of the book value of longterm debt and common equity, both of which are available in Thomson ONE Banker. The replacement value of a firm's plant and equipment is available on the firm's balance sheet, which together with the book value of the firm's total inventories form the market value of the firm's capital stock $(A)^{8}$. By definition the total earning $(E)$ equals $E E$ plus the interest expense on debt. The net asset value of the corporation's equity $(A E)$ is calculated as the firm's physical assets minus the sum of debt and preferred stock, i.e., $A E=A-D E B T-P S$. The growth rate of total earnings $(G R O W)$ is defined as the difference between the average $E$ in the most recent five years and the

\footnotetext{
${ }^{6}$ The term 'deferred tax' means 'the estimated future tax consequences of transactions and events recognised in the financial statements of the current and previous periods'. It concerns the tax treatment of most types of timing difference, which includes 'accruals for pension costs and other post-retirement benefits that will be deductible for tax purposes only when paid'. See FRS19: Deferred Tax for details.

${ }^{7}$ Difference between the asset or liability in the balance sheet and the surplus and deficit in the scheme will arise because of the related deferred tax balance and also when part of a surplus or deficit has not been recognised in the balance sheet, for example when part of the surplus in the scheme is not recoverable by the employer or when past services awards have not yet vested.

${ }^{8}$ To run the Tobin's Q regressions in Feldstein and Seligman (1981), where $A$ is needed, the sample only includes non-financial firms, thus no intangible assets are included in the calculation of $A$.
} 
previous five years, divided by $A$ and the growth of $E E$ (GROWE) is the ten-year difference in equity earnings divided by $A E$, the value of equity asset.

\section{Estimation of Market Valuation Models}

\subsection{Descriptive Statistics}

The sample covers all FTSE350 non-financial firms with at least one defined benefit pension scheme in 2001 and 2002 and cross-sectional regressions are run for each year. These were the first and second year for which pension funding status data becomes available on corporate financial statements under FRS17. The footnote disclosure ensures that the pension deficit will not reduce the assets of the firm like debt, so we are more likely to find a result similar to Feldstein and Seligman (1981). To correct for outliers, the dependent variables $(V / A$ or $V E / A E)$ are winsorized at $99 \%$ level. For total market value equations there are 129 firms in 2001 and 127 firms for 2002 whilst for equity value equations the sample size is 130 and 112 for 2001 and 2002 respectively.

Table 1 reports the mean and standard deviation for the variables used in equations (1) and (2). In both years $q_{E}$ is greater than $q$ and whilst $q$ (i.e. $V / A$ ) is close to its equilibrium value, $q_{E}$ is significantly greater than unity especially in 2001 when it is greater than 2. This reflects overvaluation in the stock market and results in the dramatic decrease of both total earnings $(E)$ and equity earnings $(E E)$ and their growth. This effect is most obvious in 2002 for equity earnings, with an average value of $-5 \%$ of equity assets and together with the large standard deviation, reflects the market crash around 2000 .

Another interesting feature is that in both cases the net debt to capital ratio remains at fairly high levels. On the one hand this reflects the shrinking market in the sample years and on the other hand the debt is so high that the tax saving it created exceeds the bankruptcy risk and this effect is especially dominant for equity variables.

In the first year of FRS17 implementation- 2001, firms have relatively low unfunded pension liabilities or are in surplus. However in 2002 the average deficit has increased dramatically to more than 10 percent of assets. This may result from pension schemes 
putting a large proportion of assets in equities, whose value decreased significantly due to the low stock returns. Facing these large pension deficits, more employers chose to close their defined benefit pension schemes to new members and the number of closures more than doubled in 2002. This observation is consistent with the discussion at the beginning of the paper that DB schemes have severe funding problems and they tend to be replaced by DC schemes. The pension deficit/surplus net of deferred tax and other non-recoverable surplus (NETPD) is less than the mean $P D$ if it's negative and vice versa because of the tax savings for pension liabilities. 


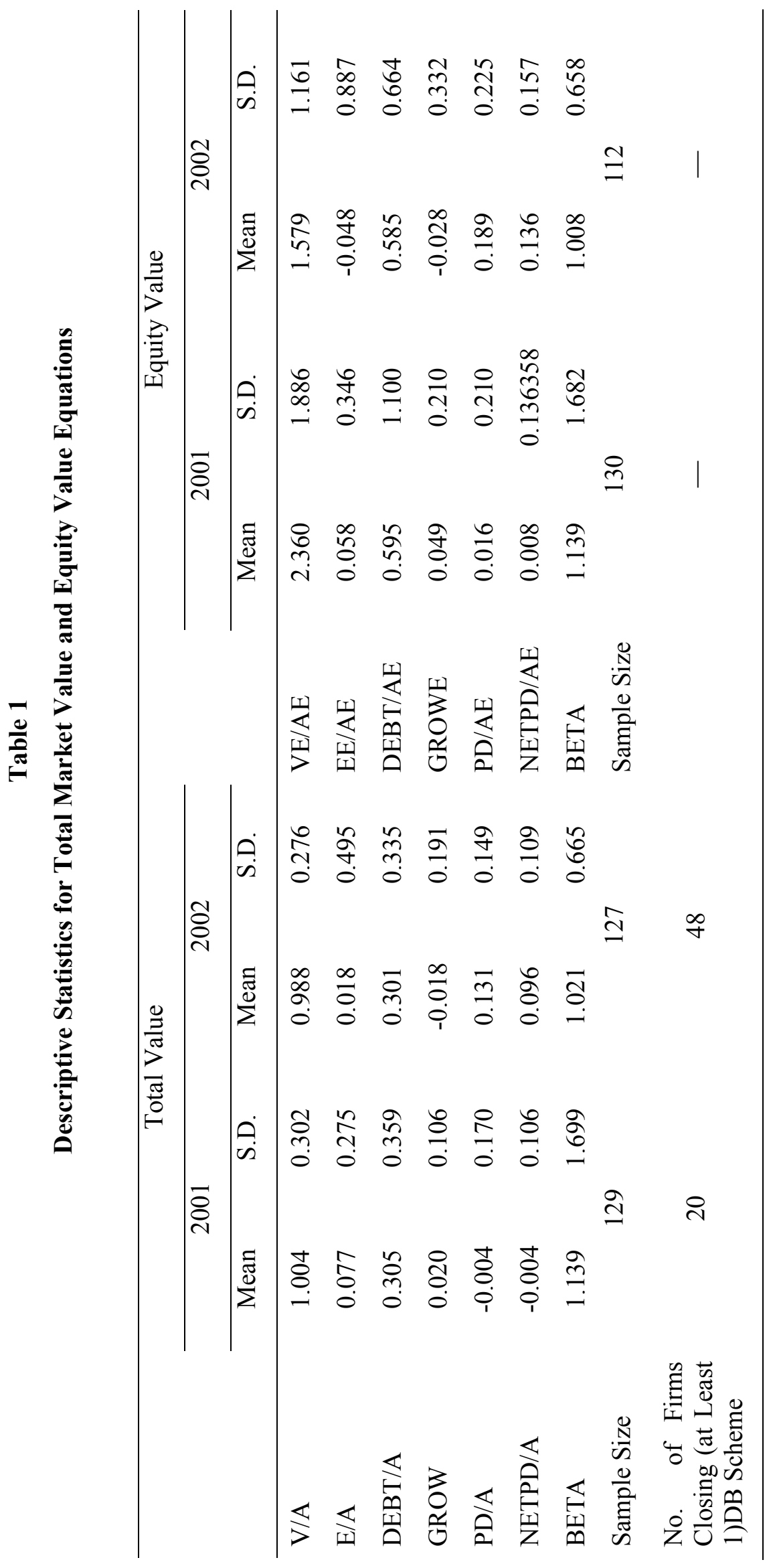




\subsection{Parameter Estimates}

Table 2 reports the parameter estimates for the total market value equation (1) for all FTSE350 nonfinancial firms with at least one defined benefit pension scheme in 2001 and 2002, the first and the second year that FRS17 was introduced. For both years the coefficient estimations of pension deficit $(P D)$ are negative but significantly different from minus one. This is consistent with the hypothesis that unfunded pension liabilities reduce the market value of the firm, although the specific point estimates suggest that unfunded pension liabilities are undervalued for most cases, which is compatible with the conclusion of Franzoni and Marin (2006).

In 2001 the coefficient of pension deficit before tax $(P D / A)$ stands at -0.46 , which implies that a $£ 1$ of unfunded pension liability reduces firm value by $£ 0.46$. The coefficient for 2002 is lower at -0.36 . For both years the point estimates for pension deficits are significantly negative, indicating that shareholders realize that there is a substitution effect between pension deficit and future pension benefit payments and reduce their current consumption level relative to total assets. Even though theory suggests that the coefficient of pre-tax pension deficit can fall between -0.7 and -1 , the point estimates for both years are consistently larger than -0.7 at a $90 \%$ confidence level. When looking at pension deficits net of deferred tax $(N E T P D / A)$ the result is more ambiguous: in 2001 the coefficient estimation is -0.8 and is compatible with the null hypothesis of a one-for-one effect whilst for 2002 the coefficient is -0.421 and is significantly smaller than 1 in absolute value.

To summarise the results, shareholders appear to realize the substitution effect of pension deficits and future pension benefit payments on future earnings. However given the point estimates of the pension deficits variable, the results are less than a one-for-one effect, indicating that pension deficits may only be partially incorporated into share prices. The results are consistent with the findings by the Pensions Regulator that 'deficits may be largely but by no means fully factored into share prices'. ${ }^{9}$ A possible explanation is that off-balance sheet disclosure of pension deficits (as required under the FRS1 17 transitional arrangement in 2001 and 2002) creates an 'accounting veil' that impedes the perfect 'value transparency' of the market (Coronado and Sharpe, 2003; Picconi, 2004). It could also be due to the uncertainty within unfunded pension liabilities. Investors may (systematically) believe that pension deficits will be smaller in the future because they think the stock market will go up or interest rate and inflation will go down. Firms will then adjust their

\footnotetext{
${ }^{9}$ PricewaterhouseCoopers LLP (2005): Paying off Pension Fund Deficits - Impact on company behaviour, share prices and the macro-economy.
} 
pension liabilities to reflect such expectations by changing assumptions underlying the valuation of pension deficits.

Table 2

\section{Coefficient Estimates for Total Market Value Equation}

Regression results for equation (1) using hand-collected data from corporate financial statement and Thomson ONE Banker. The dependent variable in each specification is the firm's total market value (debt and equity) scaled by the capital stock (firm's physical assets, including tangible assets and inventories) of the firm. The sample period is 2001 and 2002 fiscal year. Robust standard errors are shown in parentheses.

\begin{tabular}{|c|c|c|c|c|c|c|c|c|c|}
\hline Year & spec. & Constant & $\mathrm{E} / \mathrm{A}$ & GROW & DEBT/A & $\mathrm{PD} / \mathrm{A}$ & NETPD/A & BETA & $\mathrm{R}^{2}$ \\
\hline \multirow{4}{*}{2001} & 2.1 & 1.029 & -0.318 & 0.470 & -0.126 & -0.455 & & 0.023 & 0.181 \\
\hline & & $(0.037)$ & $(0.096)$ & $(0.245)$ & $(0.070)$ & $(0.148)$ & & $(0.015)$ & \\
\hline & 2.2 & 1.032 & -0.324 & 0.503 & -0.131 & & -0.798 & 0.020 & 0.194 \\
\hline & & $(0.037)$ & $(0.096)$ & $(0.244)$ & (0.069) & & $(0.235)$ & $(0.015)$ & \\
\hline \multirow{4}{*}{2002} & 2.3 & 1.012 & -0.198 & 0.293 & 0.001 & -0.356 & & 0.031 & 0.092 \\
\hline & & $(0.053)$ & $(0.078)$ & $(0.211)$ & $(0.072)$ & $(0.172)$ & & $(0.039)$ & \\
\hline & 2.4 & 1.008 & -0.205 & 0.307 & -0.001 & & -0.421 & 0.030 & 0.083 \\
\hline & & $(0.053)$ & $(0.078)$ & $(0.212)$ & $(0.073)$ & & $(0.239)$ & $(0.039)$ & \\
\hline
\end{tabular}

The stock market crash at the beginning of the new century, may have been responsible for some of the more puzzling coefficients in the market value equation. The parameter estimates of the earning variable $(E / A)$ indicates that a high ratio of earning to total assets reduces the market value of the firm. Specification 2.1 and 2.2 in Table 2 imply that in 2001 a one pound increase in after-tax earnings reduces the market value of the firm by up to 32 pence and this effect is alleviated in 2002 . However an increase in returns still reduces the firm value by about $20 \%$. Two possible reasons could have caused this anomaly. First, as indicated by the descriptive statistics, in the sample period the ratio of debt to firms' capital stock was more than 30 percent, therefore the interest expense on the debt has taken a large proportion of the total earnings and this part of the total earning obviously has less effect on a firm's future cash flows. This explanation is supported by the estimates for the equity value equation in Table 3, where earnings net of interest expense on debt are positively correlated with the market value of the firm. Second, at the time of low stock market returns, investors universally have a low expectation of future economic growth so what shareholders care about are the growth opportunities of the firm rather than the absolute value of total earnings. The positive coefficient of the growth variable $(G R O W)$ in 2001 implies that shareholders value firms that have experienced an increase in earnings during the past 10 years. 
The coefficient for the debt-to-asset ratio $(D E B T / A)$ in 2001 is around -0.13 , suggesting that a higher leverage ratio increases the bankruptcy risk of the firm and the effect diminishes in 2002. For 2001 both of the coefficients of debts and pension deficits are negative, however corporate debt and pension deficits are supposed to affect the firm value in different ways, as discussed in Section 3.3. The beta coefficient in both years has no significant explanatory power, again confirming that the market factor itself cannot account for the return pattern of the firm.

Table 3 presents the parameter estimates for the equity value equations (equation (2)). Not surprisingly, when looking at variables related to the firm's common stock equity, some of the effects driven by the high leverage ratio have disappeared. The equity earning of the firm ( $E E$, earnings excluding interest expense on debt) now is positively correlated to firm's market capitalization in 2001. Although just slightly above 90 percent confidence level, the coefficient suggests that it is the equity earnings that have more implication on the firm's ability to provide above-average earnings. The earning variable lost its explanatory power for 2002. The estimate for the growth of the equity earnings for the past 20 years (GROWE) has the right sign but is marginally insignificant.

In 2001 a higher debt-to-equity ratio increases the market capitalization of a firm by more than $75 \%$ and 2002 estimates are still positive though the magnitude reduces to about 0.67 . This is possibly because the leverage ratio in the sample years is so high that the tax advantage of the debt dominates the bankruptcy risks implied by the debt service obligation. Another explanation lies within the tradeoff theory ${ }^{10}$, which states that since the interest of debts are usually tax-deductible, managers tend to exploit this benefit of debts to the maximum extent until the benefit is fully offset by the possible cost of financial distress or credit down-grading caused by higher leverage level. According to the tradeoff theory, firms with lower bankruptcy risk or less financially distressed, often large and profitable firms with high market capitalisation, tend to borrow more.

\footnotetext{
${ }^{10}$ See for example, Myers (2001).
} 
Table 3

\section{Coefficient Estimates for Equity Value Equation}

Regression results for equation (2) using hand-collected data from corporate financial statement and Thomson ONE Banker. The dependent variable in each specification is the firm's total market capitalization scaled by the net capital stock (capital stock $(A)$ net of debt and preferred stock) of the firm. The sample period is 2001 and 2002 fiscal year. Robust standard errors are shown in parentheses.

\begin{tabular}{|c|c|c|c|c|c|c|c|c|c|}
\hline Year & Spec. & Constant & $\mathrm{EE} / \mathrm{AE}$ & GROWE & DEBT/AE & $\mathrm{PD} / \mathrm{AE}$ & NETPD/AE & BETA & $\mathrm{R}^{2}$ \\
\hline \multirow{4}{*}{2001} & 3.1 & 1.707 & 0.836 & 0.502 & 0.755 & -1.589 & & 0.119 & 0.194 \\
\hline & & $(0.217)$ & $(0.511)$ & $(0.758)$ & $(0.155)$ & $(0.738)$ & & $(0.091)$ & \\
\hline & 3.2 & 1.710 & 0.873 & 0.530 & 0.757 & & -2.165 & 0.106 & 0.187 \\
\hline & & $(0.218)$ & $(0.512)$ & $(0.766)$ & $(0.156)$ & & (1.151) & $(0.092)$ & \\
\hline \multirow{4}{*}{2002} & 3.3 & 1.405 & -0.231 & 1.014 & 0.686 & -0.711 & & -0.079 & 0.169 \\
\hline & & $(0.225)$ & (0.309) & $(0.829)$ & $(0.168)$ & $(0.495)$ & & $(0.161)$ & \\
\hline & 3.4 & 1.394 & -0.231 & 1.014 & 0.667 & & -0.810 & -0.080 & 0.163 \\
\hline & & $(0.226)$ & $(0.311)$ & $(0.834)$ & $(0.168)$ & & $(0.714)$ & $(0.162)$ & \\
\hline
\end{tabular}

The unfunded pension liabilities have a more notable effect than the total market value equation suggests. In 2001, one pound of pre-tax pension deficit reduces the market capitalization by 1.59 pounds (specification 3.1) and 2.17 (specification 3.2) pounds for deficits net of tax. Both estimates fall within the predicted value considering their standard errors. However given the magnitude of the estimates, one could argue that by making one pound of contributions, the firm's value will increase by more than one pound, of which shareholders can take advantage. Note that this kind of practice is not without cost or limit. First, pension contributions reduce the cash flows that would otherwise be used to make investment or pay dividends, which may have negative effects on share prices or harm shareholders' interests ${ }^{11}$. Second, according to the Minimum Funding Requirement, there is an upper limit for scheme overfunding, where schemes more than $105 \%$ funded have to reduce their surplus by benefit improvement or contribution decrease. The coefficients for pension data in 2002 have the right sign but lose their explanatory power. When comparing the pension coefficients of the total market value and equity value equation, one can find a more 'favourable' result for 2001 - the estimated coefficients are compatible with the expected value at a $95 \%$ or higher confidence level. One explanation is that due to the Financial Reporting Council's decision to postpone the full implementation of FRS17, according which pension deficits have to enter corporate balance sheets and income statements, shareholder may feel less urgent to pay off the full

\footnotetext{
${ }^{11}$ See Liu and Tonks (2008) for details.
} 
amount of unfunded pension liabilities to avoid dramatic changes in the debt value in the income statement.

However as pointed out by Cardinale (2005), there may exist an 'accounting bias' that gives a higher weighting to liabilities recognised in the balance sheet as opposed to off-balance sheet ones reported in the footnotes of financial statements ${ }^{12}$. If realized in the balance sheet, the unfunded pension liabilities then represent a true liability of the corporation that will reduce the asset value of the firm. Pension deficits disclosed in the balance sheet are same as the rest of the corporate debts except for the different tax treatment between the two as discussed in Section 3.2. According to the transitional arrangement of FRS17, the full implementation of the standard is due from 2005 financial year and a testable hypothesis using the data after 2005 is that pension deficits will have less, if any, impact on the market value of the firm compared to the previous sample years, when only a footnote disclosure was required for pension deficits. Table 4 reports the coefficient estimates of the total asset value and equity value equations (equations (1) and (2) respectively) using the data derived from the financial statement for 2006 financial year.

Table 4

\section{Coefficient Estimates for the Feldstein and Seligman Model Using 2006 Data}

Regression results for equation (1) and (2) using hand-collected data from corporate financial statement and Thomson ONE Banker. Panel A reports the coefficient estimates for the total market value equation (equation (1)) and the dependent variable is the firm's total market value (debt and equity) scaled by the capital stock (firm's physical assets, including tangible assets and inventories) of the firm. Panel B reports the coefficient estimates for the equity value equation (equation (2)) and the dependent variable is firm's total market capitalization scaled by the net capital stock (capital stock $(A)$ net of debt and preferred stock) of the firm. The sample period is 2006 fiscal year. Robust standard errors are shown in parentheses.

Panel A: Total Market Value Equation

\begin{tabular}{ccccccc}
\hline Constant & E/A & GROW & DEBT/A & PD/A & BETA & $\mathrm{R}^{2}$ \\
\hline 0.384 & 2.688 & -0.313 & 0.074 & 0.314 & 0.252 & 0.386 \\
$(0.274)$ & $(0.286)$ & $(0.215)$ & $(0.074)$ & $(0.371)$ & $(0.236)$ & \\
\hline \multicolumn{7}{c}{ Panel B: Equity Value Equation } \\
\hline Constant & EE/AE & GROWE & DEBT/A & PD/AE & BETA & $\mathrm{R}^{2}$ \\
\hline 1.182 & 15.651 & -0.854 & -0.327 & 1.334 & -0.457 & 0.782 \\
$(0.953)$ & $(1.040)$ & $(1.632)$ & $(0.293)$ & $(0.930)$ & $(0.817)$ & \\
\hline
\end{tabular}

\footnotetext{
${ }^{12}$ Cardinale (2005) decomposed pension deficits (for the US market) into balance sheet and off-balance sheet deficits and found a larger coefficient estimate on balance sheet deficits than off-balance sheet deficits.
} 
Panel A and B show the coefficient estimates of the basic specifications for the total asset and equity value equations. Whilst the other parameters have expected signs, the coefficient estimates of pension deficit have lost explanatory power in both cases. The point estimate for pension deficit in the total market value equation is 0.31 and is marginally insignificant. Moreover, the null hypothesis that the point estimate for pension deficit and net debt are the same cannot be rejected either (results not reported), implying that now investors treat unfunded pension liabilities entering the balance sheet no different from the rest of corporate debts. The estimate for the pension deficit in the equity value equation is 1.33. Although insignificant again, the t-statistic is obvious higher than that in the total market value equation and the point estimate is significantly different from that of net debt (results not reported). Whilst the coefficient on debt has a negative sign, a higher pension deficit will increase the market value of the firm, however both estimates are statistically insignificant.

We may summarise the market value results. First, shareholders do recognize the substitution effect between pension deficit and future pension benefit payments and incorporate this information into share prices. Second, our findings confirm the existence of the accounting veil where investors attach different weightings to balance sheet and off-balance sheet liabilities as confirmed by the different stock market sensitivities to pension deficits under the FRS17 transitional and full implementation arrangements.

\section{Estimation for the Asset Pricing Models}

\subsection{Portfolio Formation Procedure and Descriptive Statistics}

The sample consists of all FTSE350 firms (financial and non-financial) that have at least one defined benefit pension scheme and the sample period is from 2001 to 2005 financial years. On average there are 250 firms that satisfy the selection criteria each year ${ }^{13}$.

The portfolio formation is based on the methodology suggested by Fama and French (1993). In July of year $t$ the eligible firms are sorted into seven groups according to their $F R$ at the end of fiscal year $t-1$. The first group (OF) includes all the overfunded firms $(F R \leq 0)$ and the remaining six groups consist of all the underfunded firms (firms with positive $F R$ ). The 6 underfunded groups are

\footnotetext{
${ }^{13}$ Besides the criteria discussed in Section 3.3, an eligible company for year $t$ should also have a non-missing value of FR in fiscal year $t-1$.
} 
constructed as following: group 1 to group 4 are the first four quintiles of the distribution of $F R$ and group 5 and 6 are the 9th and the 10th deciles of the underfunded firms so these are the most underfunded firms. The reason for constructing the portfolios in this way is that the sample size is smaller than Franzoni and Marin (2006) and moreover, theory suggests that pension deficits should have little or no effect for less underfunded firms. Thus only the most underfunded firms are partitioned into deciles, where the effect of pension deficit is most prominent. Upon forming the $F R$ portfolios, monthly value weighted and equally weighted portfolio returns are calculated for each group from the July of year $t$ to the June of year $t+1$. This process is iterated annually so in total there are 60 sample months for fiscal years 2001 to 2005.

Table 5 reports the descriptive statistics for the $7 F R$ portfolios. Panel A presents the funding status and the market capitalization of the portfolios. The overfunded firms have on average $7.5 \%$ surplus and for underfunded firms the funding ratio ranges from $0.7 \%$ to $39.4 \%$ percent. The size data indicates that small firms cluster in groups 5 and 6 - the most underfunded groups - and they also have the highest book-to-market ratio, implying that they are value-firms and are most likely to be undervalued. The average number of overfunded firms is 32 , however this is mainly due to the large number of firms with positive $F R$ in 2001, which is up to 72 firms. On average there are 39 underfunded firms in each quintile of the distribution for negative $F R$.

Panel B of Table 5 reports the means and standard deviations for the returns of the value-weighted and equally-weighted portfolios over the 60 sample months from July 2002 to June 2006. The average returns of the most underfunded firms for both portfolios are not obviously any lower than the other groups of firms as indicated by the asset pricing model and neither is there a clear pattern in the distribution of the returns. Moreover there is no sign of a market value effect from the mean returns (as discussed in fn. 16). Portfolio 1, which has the least negative $F R$ and therefore likely to have low book-to-market and low return, tends to have the highest earnings for both value-weighted (2.04\%) and equally-weighted cases (1.74\%). Although the most underfunded firms do not have the lowest raw returns their returns are also not comparatively higher than other $F R$ portfolios, with the only exception being the value-weighted return for portfolio 6 , which stands at a rather high level of $1.42 \%$. The last panel of Table 5 presents the means and standard deviations for the Fama-French factors. 


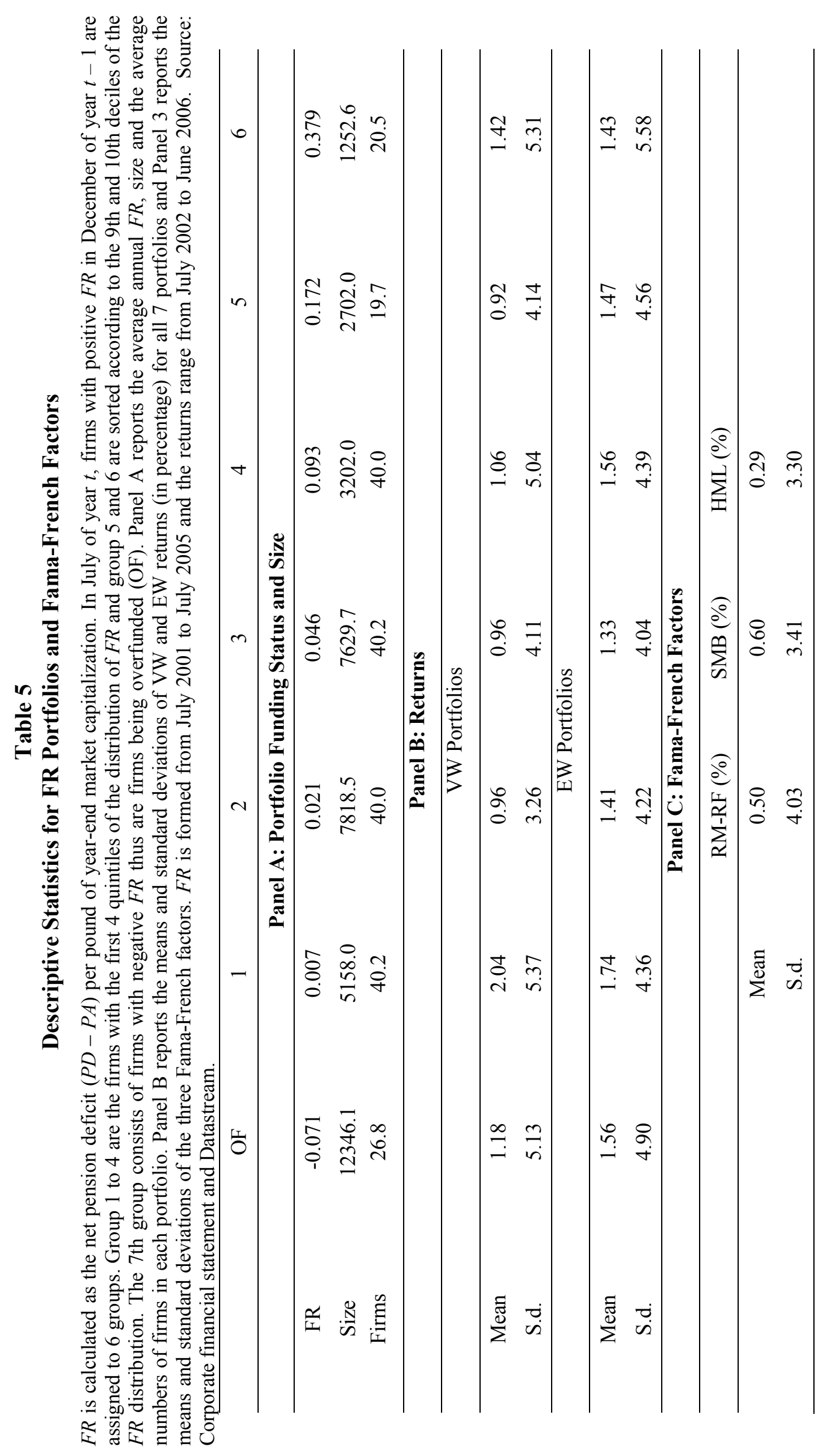

さ 
To test whether the most underfunded companies earn lower returns and whether the low returns persist over the subsequent years, VW and EW compound average returns are calculated for all 7 FR portfolios for the first 6 months (Y0.5) and the next three years (Y1, Y2, Y3 respectively) after portfolio formation and the results are presented in Table 6. Note that for the five sample years, compound returns are computed even though the full range of time-series data are not available for portfolios other than 2001 and 2002 with the intention that this will largely eliminate extreme numbers. Therefore returns in $\mathrm{Y} 0.5$ and $\mathrm{Y} 1$ are mean returns for the whole sample period but $\mathrm{Y} 2$ are mean returns for 2002, 2003 and 2004 and Y3 consists of only 2002 and 2003 returns.

In the first six months after portfolio formation, portfolio 1 - the least underfunded firms - earns universally higher returns than the rest of the portfolios. The VW return is $18.3 \%$ annually and that's more than $10 \%$ higher than the second largest return, and for the EW case the return is $8.64 \%$, still more than $2.5 \%$ higher than the rest of the portfolios. This finding is confirmed by the FamaFrench three-factor regression that portfolio 1 earns significantly positive abnormal returns compared to the other portfolios. The reason why the VW return of OF portfolio is quite low is because the number of overfunded firms is only a small proportion for the whole sample and some firms (e.g. BP) of large size have low returns for the sample period, which is evident because when equally weighting returns, the effect vanishes.

The raw returns on the most underfunded firms confirm the findings from sample descriptive statistics. The only exception is the VW return for portfolio 5, the second most underfunded portfolio, whose return is $0.45 \%$ for the first 6 months. However after one year of portfolio formation (Y1) its return has increased to $11.40 \%$ and is no longer much smaller than those of the other portfolios. Most likely to be small and value firms, portfolio 6 exhibits comparatively higher returns than the rest of the underfunded portfolios except for portfolio 1 . The high return persists for up to 2 years although the relative difference between the returns decreases yearly. When firm size is not considered, Panel B of Table 6 shows that the EW return for portfolio 6, 2 years after portfolio formation increases to $50 \%$ annually — nearly double that of the VW case-and this is likely to be caused by the high returns for small companies. The overall evidence shows that there is no significant evidence of mispricing for the most underfunded firms using the raw return data. 


\section{Table 6}

\section{Raw Returns}

$F R$ is calculated as the net pension deficit $(P D-P A)$ per pound of year-end market capitalization. In July of year $t$, firms with positive $F R$ in December of year $t-1$ are assigned to 6 groups. Group 1 to 4 are the firms with the first 4 quintiles of the distribution of $F R$ and group 5 and 6 are sorted according to the 9th and 10th deciles of the $F R$ distribution. The 7th group consists of firms with negative $F R$ thus are firms being overfunded (OF). For each year the portfolio is constructed, monthly returns are compounded in the first six months (Y0.5) and the following three years $\left(\mathrm{Y}_{i}\right)$ without reforming the portfolios. Panel A and Panel B reports the mean compounded returns for VW and EW portfolios. FR is formed from July 2001 to July 2005 and the returns range from July 2002 to June 2006. Source: Corporate financial statement and Datastream.

\begin{tabular}{|c|c|c|c|c|c|c|c|}
\hline \multicolumn{8}{|c|}{ VW Returns } \\
\hline & \multirow{3}{*}{$\mathrm{OF}$} & \multirow{3}{*}{1} & \multirow{3}{*}{2} & \multirow{3}{*}{3} & \multirow{3}{*}{4} & \multirow{3}{*}{5} & 6 \\
\hline & & & & & & & \multirow{2}{*}{$\begin{array}{c}\text { Most } \\
\text { under0funded }\end{array}$} \\
\hline & & & & & & & \\
\hline Y0.5 & 1.10 & 18.13 & 2.59 & 6.59 & 2.73 & 0.45 & 6.83 \\
\hline Y1 & 11.97 & 23.28 & 8.59 & 10.74 & 12.39 & 11.40 & 19.68 \\
\hline Y2 & 19.92 & 21.86 & 20.41 & 17.08 & 22.34 & 29.59 & 30.92 \\
\hline Y3 & 23.51 & 22.42 & 26.54 & 11.07 & 17.94 & 29.92 & 24.97 \\
\hline \multicolumn{8}{|c|}{ EW Returns } \\
\hline & OF & 1 & 2 & 3 & 4 & 5 & 6 \\
\hline Y0.5 & 6.11 & 8.64 & 2.62 & 3.37 & 5.01 & 5.49 & 5.25 \\
\hline Y1 & 17.94 & 21.43 & 15.36 & 14.52 & 19.33 & 19.74 & 22.93 \\
\hline $\mathrm{Y} 2$ & 28.16 & 29.33 & 29.02 & 20.82 & 23.81 & 27.57 & 50.10 \\
\hline Y3 & 22.16 & 23.17 & 19.53 & 18.68 & 20.48 & 26.94 & 24.77 \\
\hline
\end{tabular}

\subsection{Parameter Estimates for the Factor Model}

The time-series regression from equation (4) shows that the return pattern indicated in the portfolio mean returns are even more pronounced after adjusting for risk. The parameter estimations are reported in Table 7. 


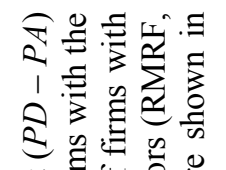

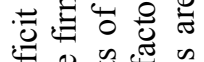
式导.

.

जै

는

$\Rightarrow$ On

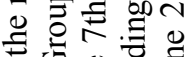

๖。

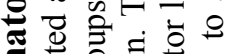

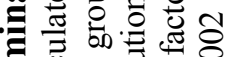

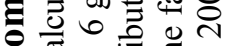

정욜

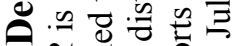

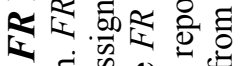

๘ हो

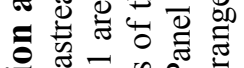

类

งึ

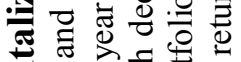

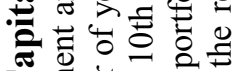

U छ

牙 政

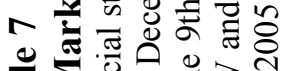

능 元

o0

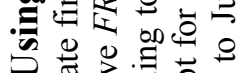

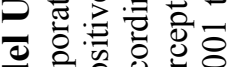

융 \&

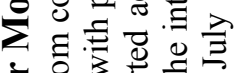

sิ

选进边

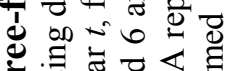

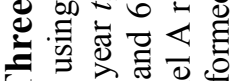

更岁的密

ड

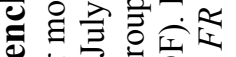

氙的包的

究

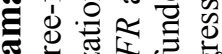

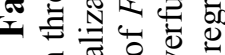

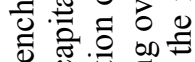

항. 일

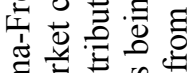



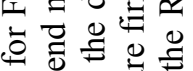

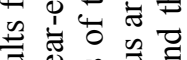

จ유

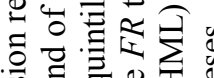

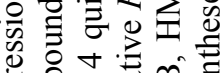

6

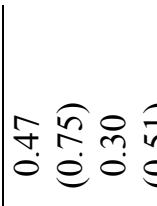



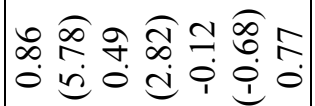

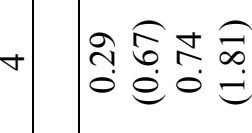

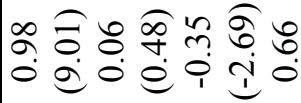

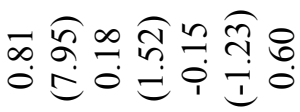

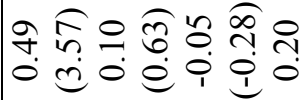

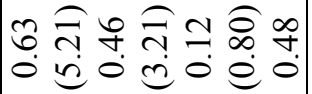

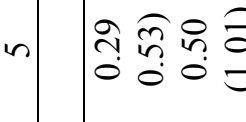

잉

i 000

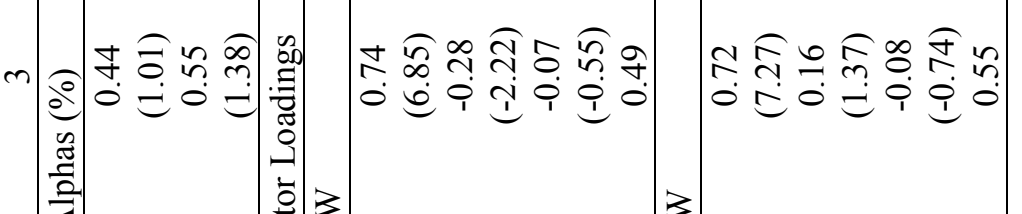



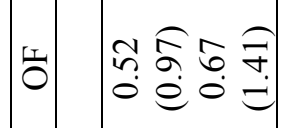

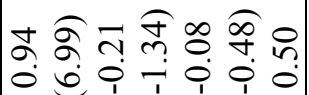

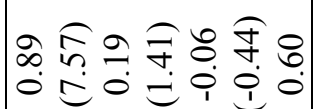

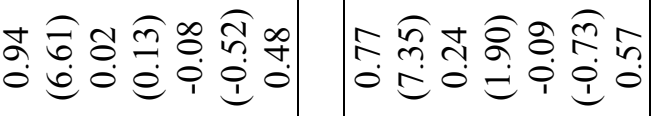

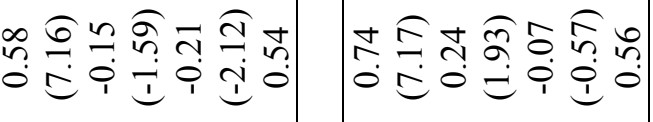

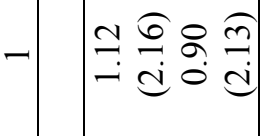

3

$\hat{\sim}$ 
Panel A shows the intercepts for both VW and EW portfolios. Consistent with the findings from the raw returns of portfolio 1, which contains underfunded firms with the lowest $F R$, all portfolios have significantly positive intercepts. For instance, portfolio 1 has an alpha of $1.12 \%$ for VW returns, which is more than $14 \%$ annually. The number for the EW portfolio return is lower but still compounds to more than $10 \%$ per year. Although the most underfunded portfolios - on average likely to be small and value companies - do not show high abnormal returns, the alphas are not significantly different from zero. Setting the significance level aside, the fact that the most underfunded firms (portfolio 5 and 6) have relatively lower alphas, imply that firms with the most severe funding status are overvalued, but the negative impact of pension deficit is offset by some positive effects ${ }^{14}$. These effects could be the market value effect discussed in Section 3.3, or the highly positive abnormal returns after 2003 following the stock market downturn in the previous few years. Notice that the alpha is not significantly different from zero either for overfunded firms, which is consistent with the findings of Franzoni and Marin (2006). The asymmetry effect of overfunded and underfunded plans can be explained by managerial short-termism (Stein (1989)), where firms can immediately use the overfunding to increase current earnings and cash flows so there is no delay between the materialisation of the overfunding and its positive impact on stock returns ${ }^{15}$. In unreported tests where overfunded firms are not separated from the sample, the regression shows a similar return pattern, showing that there is no misvaluation for overfunded firms.

Panel B of Table 7 reports the factor loadings for the portfolios. Consistent with the argument that the most underfunded firms are small firms, portfolios 5 and 6 have the highest loadings on SMB and $H M L$. Given the high standard deviation of returns for this portfolio, it also tends to have high market beta. Given the regression results, there appears to be no sign of any systematic misvaluation for highly underfunded firms using the FR measurement of funding status from equation (3). Robustness tests were run using different denominators (such as total assets) and for firms of different book-to-market ratios, but these changes did not alter the results. In order to check whether there may be time effects in the regressions, the three-factor model was run in a panel data regression with fixed year effect (results not reported), again however this does not alter the results from cross-sectional regressions significantly.

\footnotetext{
${ }^{14}$ The reason why in some cases the most underfunded portfolio (portfolio 6 in VW case) has higher abnormal returns than the second-most underfunded firms is believed to be caused by the outliers within portfolio 6 .

${ }^{15}$ Recall that the earnings surprise arises from such delay between the between the materialisation of the underfunding (through pension contributions) and its negative impact on stock returns.
} 
Besides the short sample period and the size effect that might have caused these results? There are two more possible explanations. First, the results could imply that the wrong asset pricing model has been chosen. Kothari and Warner (1997) show that tests for long-run abnormal returns associated with specific events are severely mis-specified if the wrong model is chosen, which rapidly compounds to give large errors. Although the calendar-time portfolio suggested by Lyon, Barber and Tsai (1999) (and the model used by Franzoni and Marin (2006) and in this paper) provides an effective improvement for the compounding problem, it only performs well in random samples and the misspecification is still pervasive in non-random samples, which is the basis of the portfolio formation in this paper. A 'bootstrapping' approach may provide a solution to the problem. However even with more years of data, given the number of firms in each $F R$ portfolio, this approach is not feasible with the current list of firms. Second, the results may be due to the UK's pension funding regulations. According to the minimum funding requirement (MFR) (Pensions Act 1995), schemes with large deficits do not need to make up the shortfall instantly but only need to do so over several years (usually three years for most underfunded schemes and up to ten years for less underfunded schemes). This is different from the US system, where firms must make annual contributions equal to the deficit of the plan plus any benefit cost accrued during the year. Therefore in the UK, pension contributions made to cover the deficit are smoothed over a number of years, and the financial pressure they impose on earnings may not be as prominent as for US firms. Of course this situation changed with the introduction of the Pensions Act 2004. In unreported results, although we have included one extra year of data for the year 2005, under the new funding regulations into our analysis, this does not have any significant impact on the overall results.

\section{Conclusions}

We have argued that there are two related implications of the stock market efficiently incorporating information about pension fund deficits into share prices. First, if shareholders correctly realise that unfunded pension liabilities are a future obligation that must be paid out of the assets of the firm, then unfunded pension liabilities are like an equal amount of debt, and will reduce the firm's market value accordingly. Second, firms with large unfunded pension liabilities will be required to make futures contributions to the pension schemes, which will reduce the future profits of the firm. If share prices fully incorporate the effect of lower future earnings, then when lower future earnings are announced there should be no effect on share prices. Conversely if the market fails to 
incorporate the effect of funding the deficit, there will be negative surprises in the market when earnings start to drop and negative abnormal returns will be observed.

This paper empirically tests the above hypotheses for the UK market using two alternative methodologies, namely the market valuation model and the asset pricing model. Using a sample of UK FTSE350 firms with defined benefit pension schemes, we find that unfunded pension liabilities do reduce the market value of the firm but the coefficient estimates indicate a less than one-for-one effect. This is probably because as FRS17 transformed from transitional arrangement to full implementation, unfunded pension liabilities are required to enter the balance sheet and this will reduce the substitution effect of pension deficit on shareholders' consumption. Another possible explanation arises from the uncertainty within unfunded pension liabilities. Investors may (systematically) believe that pension deficits will be smaller in the future because they believe the stock market will go up or interest rate and inflation will go down. Firms will then adjust their pension liabilities to reflect such expectations by changing assumptions underlying the valuation of pension deficits. This view may explain why the stock market sensitivity to pension deficits approaches the theoretically one-for-one effect when we account for the possible assumptions (e.g. discount rate and accounting methods) underlying the calculation of pension deficits in the market valuation model. Our findings are consistent with those observed by the Pensions Regulator, that 'deficits may be largely but by no means fully factored into share prices'.

In addition, consistent with the findings from the market valuation model, there is no significant evidence of negative abnormal return for highly underfunded schemes and the results are not subject to the choice of funding status measure and portfolio formation procedures. However we do find that firms with better funded pension schemes earn higher returns regardless of the size of the firm and negative abnormal returns are found in firms with severely underfunded pension schemes even for firms with high book-to-market ratio, which means they should have a higher return. The overall findings indicate that firms with large pension deficit have lower earnings but the effect is possibly offset by the possible positive impact to earnings due to the overvaluation in portfolios with large funding ratio. The results could also be caused by the pension contribution regulations in the UK, where pension contributions made to cover the deficit are smoothed over a number of years and the financial pressure they impose on earnings is consequently weakened. 
Our results are in line with the 'classical' market valuation model by Feldstein and Seligman (1981), implying that the change of the reporting regulations in a pension scheme deficit in an employer's accounts is likely to impact on the market's assessment of the employer's value. However these effects may have been affected by the FRS17 transitional arrangements that unfunded pension contributions are not required to be disclosed in the balance sheet, and will not fully reduce the value of the firm even though pension deficits represent a true liability of the firm. This has been changed as the UK fully implements FRS17/IAS19 accounting standard where after-tax pension deficit must enter the balance sheet as retirement benefit liabilities. Moreover, the new Pensions Act (2004) has introduced a new firm-specific and non-smoothed funding rule for UK defined benefit pension schemes, which will certainly apply pressures on highly underfunded firms. All the aforementioned regulatory changes may alter the results in this paper and it remains an interesting question to see how market and shareholders react to pension deficits as a true balance sheet liability after the new regulations have been implemented. 


\section{Appendix: Variable Definitions}

V

A

E

GROW

BETA

$D E B T$

$P S$

$A E$

EE

GROWE

$P D$

NET PD

$V E$

Control Variables

$P A B$

$P A E$

NO. PLAN

PERPD

PUAA

$P U$

$D C$

$H Y B$
Market value of the company, i.e. market capital, long term debt + common equity.

Firm's capital stock, plant \& equipment + total inventories

Total earning, Net Income Available to Common + interest expense on debt

Difference of 5-year average ACCOUNTING earning/A

As in Datastream

Company's net debt.

Preferred stock

A-DEBT-PS, asset value of equity

Equity earning, total earning - interest payment on debt, Net Income Available to Common in Datastream.

10-year EE growth/AE

Pension deficit from company annual report: pension liability - pension asset

Pension deficit net of deferred tax and other non-recoverable surplus.

MV of common stock. Share outstanding $\mathrm{x}$ end of year share price.

Pension asset invested in bonds

Pension asset invested in equities

Number of (principal) schemes in one company

Pension deficit per thousand scheme members

$=1$ if the firm uses the combination of projected unit and attained age method to calculate the PV of pension assets.

$=1$ if the firm uses the combination of projected unit method to calculate the PV of pension assets.

$=1$ if the firm has at least one defined contribution pension scheme besides DB plans.

$=1$ if the firm has at least one hybrid pension scheme besides DB plans. 


\section{References}

Bernard, V., and J. Thomas, 1990, Evidence that stock prices do not fully reflect the implications of current earnings for future earnings, Journal of Accounting and Economics 13, 305-341.

Bulow, J., R. Morck, and L. H. Summers, 1987, How does the market value unfunded pension liabilities? in Z. Bodie, J. Shoven, and D.Wise, eds.: Issues in Pension Economics (Chicago: UCP).

Cardinale, M., 2005, Corporate pension funding and credit spreads, Watson Wyatt Technical Paper.

Chan, K., L. Chan, N. Jegadeesh, and J. Lakonishok, 2006, Earnings quality and stock returns, Journal of Business 79 , 1401-1082.

Coronado, J. L. and S. A. Sharpe, 2003, Did pension plan accounting contribute to a stock market bubble?, Brookings Papers on Economic Activity 1, 323-359.

Fama, E., and K. French, 1993, Common risk factors in the returns on stocks and bonds, Journal of Financial Economics 33, 3-56.

Feldstein, M., 1978, Do private pensions increase national savings? Journal of Public Economics 10, $277-293$.

Feldstein, Martin, and Randall Morck, 1983, Pension funding decisions, interest rate assumptions and share prices, in Zvi Bodie and John B. Shoven, eds.: Financial Aspects of the U.S. Pension System (Chicago: UCP).

Feldstein, M. and S. Seligman, 1981, Pension funding, share prices, and national savings, Journal of Finance 36, 801824.

Franzoni, F. and J. M. Martin, 2006, Pension plan funding and stock market efficiency, Journal of Finance 61, 921-956.

Klumpes, P. J. M., and K. P. McMeeking, 2007, Stock Market Sensitivity to UK Firms? Pension Discounting Assumptions, Risk Management and Insurance Review 10 (2), 221-246.

Klumpes, P. J. M., and M. Whittington, 2003, Determinants of actuarial valuation method changes for pension funding and reporting: Evidence from the UK, Journal of Business Finance and Accounting 30 (1) \& (2), 175-204.

Liu, W. and I. Tonks, 2008, Corporate Expenditures and Financing Constraints Imposed by Pension Funding Status, Xfi Centre for Finance and Investment, mimeo

Lyon, J., B. M. Barber and C. Tsai, 1999, Improved methods for tests of long-run abnormal stock returns, Journal of Finance 54, 165-201.

Modigliani, F. and M. Miller, 1958, The cost of capital, corporation finance, and the theory of investment, American Economic Review 48, 261-97.

Picconi, M., 2004, The Perils of Pensions: Does Pension Accounting Lead Investors and Analysts Astray, Working Paper, Cornell University.

PricewaterhouseCoopers LLP, 2005, Paying off Pension Fund Deficits - Impact on company behaviour, share prices and the macro-economy.

Tobin, J., 1969, A general equilibrium approach to monetary theory, Journal of Money Credit and Banking 1, 15-29. 